\title{
Speak softly and carry a big stick: hardening soft governance in EU energy and health policies
}

\section{Journal of Environmental Policy and Planning}

\author{
Pierre Bocquillon $^{1}$, Eleanor Brooks ${ }^{2 *}$ and Tomas Maltby ${ }^{3}$ \\ ${ }^{1}$ University of East Anglia, School of Politics, Philosophy and Language, Norwich Research Park, \\ Norwich, NR4 7TJ. P.Bocquillon@uea.ac.uk \\ $2^{2 *}$ University of Edinburgh, School of Social and Political Science, Chrystal Macmillan Building, 15a \\ George Square, Edinburgh EH8 9LD (corresponding author) Eleanor.brooks@ed.ac.uk \\ ${ }^{3}$ King's College London, Department of Political Economy, Bush House NE Wing, 40 Aldwych, \\ WC2B 4BG. Tomas.maltby@kcl.ac.uk
}

\section{Biographical notes}

Dr Pierre Bocquillon is a Lecturer in European Politics at the University of East Anglia (Norwich, UK). He completed his $\mathrm{PhD}$ in Politics and International Studies at the University of Cambridge. He works on energy and climate change politics in Europe, as well as on European politics more generally. His current research interests include the external dimension of the EU's energy and climate policies, the politics of renewable energy promotion and the democratic governance of energy and climate change.

Dr Eleanor Brooks is a Career Development Fellow in the Global Health Policy Unit at the University of Edinburgh. She completed her PhD at Lancaster University. Eleanor's research focuses on EU health governance, considering the EU's role in health and the politics of EU health policy and law. This includes work relating to the reform of the European Commission under President Juncker, the role of advocacy coalitions in EU health policy development and the dismantling of public (health) policy at the European level.

Dr Tomas Maltby is a Lecturer in International Politics in the Department of Political Economy, King's College London. He completed his $\mathrm{PhD}$ in Politics at Manchester University. Tomas' research focuses primarily on climate and energy policy. His research considers understandings of security in the development of climate and energy policy at the European and nation state level. This includes work related to energy transitions, the securitisation of energy, climate scepticism and also work on the politics of air pollution. 


\begin{abstract}
This paper analyses a shift in EU governance characterised by the proliferation of soft governance frameworks incorporating 'harder' elements, labelled 'harder soft governance'. We examine two policy areas - health and energy - where strikingly similar governance architectures - the European Semester and the Energy Union Governance Regulation - are now core governance tools. We use the Experimentalist Governance framework, supplemented with the harder features of 'harder soft governance', drawing on a qualitative comparative case study approach and an original set of elite interviews, to address two questions: (1) What instruments, processes and actors do the Semester and the Governance Regulation involve? and, (2) What is driving the governance shift in these areas? We show that, in both cases, 'harder soft governance' has emerged out of incomplete competences and sovereignty concerns. In health, this shift has been driven primarily by the creative entrepreneurship of health actors, whilst in energy it results from the need to ensure cooperation while respecting member states' concerns. We conclude, drawing on the more extensive experience of health in the Semester, that the introduction of policy coupling, the strategic approach of key actors and the potential for crisis politics will shape the future of energy governance.
\end{abstract}

\title{
Key Words
}

Health Policy, Energy Policy, European Union, Experimentalist Governance, New Modes of Governance 


\section{Introduction}

A strengthening of soft governance is being seen across many European Union (EU) policy areas (Graziano \& Halpern, 2016; Ringel \& Knodt, 2018). This has been conceptualised as a 'harder soft [mode of] governance' (HSG) whereby policy instruments with a 'soft' basis such as peer review or policy monitoring - are supplemented with a 'harder' element - for instance, by making the outcomes of peer review public, or by applying sanctions where monitoring reveals shortcomings (see Knodt \& Schoenefeld, forthcoming).

HSG is understood here as an evolution of the 'new' modes of governance (NMGs) in EU policy-making, which emerged in the 1990s to address the legitimacy challenges faced by the traditional Community Method, ${ }^{\mathrm{i}}$ and to circumvent gaps in EU competence which made authority-based governance legally and politically unacceptable (Eberlein \& Kerwer, 2004). For instance, the open method of coordination (OMC), the most commonly cited NMG, creates forums where national governments and EU institutions coordinate to agree guidelines, report on national progress, share best practice and monitor performance against benchmarks, but do not commit to harmonised approaches or enforced targets (European Council, 2000; Trubek \& Trubek, 2005).

Though the OMC has enjoyed some success, its reliance on the willingness of national governments to initiate policy change has limited compliance and more recent NMGs have begun to include elements of HSG (de la Porte \& Heins, 2016). The European Semester is a prime example of this dynamic. Mirroring many of the features of the $\mathrm{OMC}$, the Semester is an annual cycle of analysis, reporting, recommendations and evaluation, 'hardened' by the potential for sanctions where member states fail to implement recommendations. After almost a decade of operation, the Semester has become the core tool of the EU's economic governance. We argue that its balance of softer and harder elements is now being mirrored elsewhere, 
including in the new Regulation on the Governance of the Energy Union and Climate Action (hereafter Governance Regulation).

This article uses the Semester to explore how soft governance has hardened, the extent to which energy governance has developed in a similar way, and what implications this might have for energy policy. It addresses two research questions: (1) what instruments, processes and actors do the Semester and the Governance Regulation involve? And, (2) what is driving this shift in governance?

The article first outlines the analytical framework, combining Experimentalist Governance with the harder elements identified by HSG, and the methodological approach used. We then introduce the European Semester and its particular instruments, processes and actors, highlighting its 'harder' elements of governance and parallels with the Governance Regulation. The third section explores what is driving the proliferation of HSG, drawing on the legal and political contexts of health and energy policy, as well as the literature on the drivers of NMGs. We show that, in both cases, 'harder soft governance' has emerged out of incomplete EU competences and member states' sovereignty concerns in core areas. In health, the governance shift has been driven by the creative entrepreneurship of health actors, whilst in energy it results from the need to ensure cooperation under the Commission's monitoring role, while respecting member states' concerns about control over sensitive aspects. Drawing on the experience of health in the Semester, we conclude that the introduction of policy coupling, the strategic approach of key actors and the potential for crisis politics will shape the future of energy governance.

\section{Analysing the new modes of governance, from soft to hard(er)?}

We understand both the Semester and the Governance Regulation to be examples of NMGs. We draw on Sabel and Zeitlin's (2010) Experimentalist Governance framework, which 
provides a structure to identify the constitutive features of NMGs, and combine this with the harder features identified by HSG (Knodt \& Schoenefeld, forthcoming), to assess the governance shifts in the Semester and the Governance Regulation.

\subsection{Experimentalist Governance and its limitations}

Whilst there is no definitive framework for analysing the NMGs, Sabel and Zeitlin's (2010) Experimentalist Governance framework is useful to identify their key features and logics. It provides a clearly defined template to analyse the various instruments and mechanisms involved in the Semester and the Governance Regulation. Sabel and Zeitlin (2010a, p. 13) characterise Experimentalist Governance as consisting of four key elements, linked in an ongoing, iterative cycle. First, broad 'framework goals' are agreed jointly at the higher governance level, and metrics are adopted so that progress can be measured. Second, responsibility for pursuing these goals is given to the 'lower level units' and these units are given considerable discretion to adopt any measure they see fit to achieve them. Third, the condition of this discretion is that lower level units report regularly on their activities, undergo peer review of their performance and justify their decisions publicly; this facilitates scrutiny, contestation and participation by a wider range of actors (Sabel \& Zeitlin, 2008). Finally, the

goals, metrics and procedures of decision-making themselves are periodically revised in response to learning in the earlier stages, and the cycle repeats.

This model is predominantly soft, based on learning and cooperation, and makes little mention of hardened governance elements. An exception to this, however, is the concept of 'penalty defaults' - mechanisms that underpin experimentalist regimes and induce parties to cooperate by raising the costs of inaction and making the alternative to the proposed cooperation 'sufficiently unpalatable' (Sabel \& Zeitlin, 2010a, p. 14). Giving the examples of market 
exclusion, or threat of regulatory intervention or trade sanctions, Keohane and Victor's description is instructive:

'A penalty default...is a form of enforcement that does not prescribe solutions which may be impossible to agree on because states likely to be targeted will block them - but that forces the actors to cooperate unless they are willing to risk losing control of their joint fate' (2015, p. 207).

Sabel and Zeitlin draw a sharp distinction between penalty defaults and the 'shadow of hierarchy' view of NMGs (e.g. Héritier \& Lehmkuhl, 2008). For them, the latter refers to the ability of authorities to impose an unwanted outcome on cooperating parties in case of lack of agreement, inducing them into reaching a compromise. In contrast, penalty defaults involve an alternative to cooperation that is 'so manifestly unworkable to the parties as to count as a draconian penalty' (Sabel \& Zeitlin, 2008, p. 308); it therefore does not require the potential intervention of a superior authority to induce cooperation. This idea is tied to the condition of uncertainty which underlies Experimentalist Governance and does not presuppose hierarchical mechanisms. Beyond this concept, the framework provides little to identify mechanisms that are aimed at ensuring not only cooperation, but compliance. To compensate for this, we draw on the features of HSG as outlined by Knodt \& Schoenefeld (forthcoming).

\subsection{Harder soft governance as a supplementary perspective}

Knodt and Schoenefeld (forthcoming) observe a recent trend in the inclusion of harder elements in soft governance arrangements by the Commission, as well as in other policy arenas. In conceptualising HSG they identify a series of mechanisms, introduced into governance frameworks, through which hardening can take place. These include: 'Hard' targets or implementation mechanisms which reshape voluntarism; naming, blaming and shaming via publication of rankings, reports and other information; institutionalising political entrepreneurs and strengthening their role; requiring justification of (in)action by member states; coupling 
policy fields to create linked (dis)incentives; introducing sanctions or penalties for noncompliance; and including a mandate for Commission tertiary legislation. They acknowledge that this is not an exhaustive list and encourage empirical studies to identify additional mechanisms; this article responds to that call by exploring the existence of HSG within the Semester and the Governance Regulation. The elements above are summarised in table 1 (page 20 below), along with additional mechanisms of hardening observed in the cases of health and energy policy.

\subsection{Drivers of the shift in governance}

In seeking to address our second question, in which we analyse the interests and political dynamics that are driving the development of HSG, we encounter a further limitation of both the Experimentalist Governance and the HSG models, in that neither is intended to provide an explanatory framework. As such, we turn here to the literature on NMGs and its understanding of why non-traditional governance architectures have become a significant feature of EU governance.

There are three primary lines of argument which explain the motivations for adopting NMGs. The first holds that NMGs enable the EU, and particularly the Commission, to extend its authority and influence into areas from which it is excluded. Dehousse (2016) argues that, though there has been a decline in hard legislative output which coincides with the proliferation of NMGs, the EU's governing capacity has not been weakened, but rather has been extended into new fields. Similarly, Caporaso and Wittenbrinck (2006) frame the introduction of the NMGs as a response to the question of 'where to next?' for European integration, after the establishment of the Single European Act and the Economic and Monetary Union, indicating their role in policy expansion. 
A second, related, argument focuses on the ability of NMGs to address the issue of noncompliance with hard law. Decision-makers might adopt soft law in the expectation that it will act as a precursor to hard law, or so as to use the threat of this potential evolution to push parties into compliance (Maher, 2004). More constructively, some see NMGs as a mechanism to address non-compliance via processes of learning and creation of common norms (Radaelli, 2008; Zeitlin, 2005). Though Saurugger and Terpan (2016) find that compliance with soft law is no more common than with hard, the potential to overcome paralysis resulting from vetoes remains a core motivation for using NMGs (Caporaso \& Wittenbrinck, 2006).

Finally, concerns about sovereignty are understood as key motivators for the introduction of NMGs. A core advantage of soft law over hard law, as identified by Abbott and Snidal, is that it is easier to agree than hard law, and this is 'especially true when the actors are states that are jealous of their autonomy and when the issues at hand challenge state sovereignty' (2000, p. 423). In this view, the use of NMGs is driven by a need to convince member states that 'convergence is possible without major sovereignty losses' (Saurugger \& Terpan, 2016, p. 58) in pursuit of a common goal. Taking these understandings of what is driving the proliferation of NMGs as a starting point, we explore the motivations behind the governance shifts in the case studies.

\subsection{Methodology}

When examining the causal processes behind the proliferation of HSG in particular sectors, the historical political and legal contexts of these sectors is important. Since the Semester is a horizontal governance architecture (Borras \& Radaelli, 2011), its recommendations target a range of policy areas; as such, we use its impact upon health policy as a case study to draw insights about the potential impact of the Governance Regulation on energy policy. The two sectors share considerable similarities. In both, competences are shared and, whilst the EU has 
accumulated significant influence, national governments remain wary of ceding competence. Integration has relied on the application and extension of internal market rules, as well as interdependency with related policy areas, such as competition, trade, security and climate, reflecting the 'nexus quality' of both sectors (Ringel \& Knodt, 2018, p. 210; Müller et al., 2015). In both, dedicated legal bases were only established more recently, at Maastricht (for health) and Lisbon (for energy), and only enable use of the ordinary legislative procedure in specific issue areas, which include renewable energy, the internal energy market and energy efficiency, and public health. In areas of greater sensitivity - such as the energy mix, and the organisation and financing of health systems - the EU is restricted to soft governance.

The article's empirical basis is a primary documentary analysis and data from 21 semistructured anonymous elite interviews. The latter were conducted between 2015 and 2018 with key actors, including those representing EU institutions and member states (see appendix 1). Documentary analysis included the core documents of the European Semester and of the Governance Regulation, and mapped the instruments, processes, mechanisms and actors involved in each governance architecture.

\section{The experimental governance of the European Semester and Energy Union}

This section considers the first research question - how are health and energy governed, and what instruments, processes and actors are involved? The extent to which these policy areas are governed by an experimentalist structure is discussed, and we highlight where elements of HSG are additionally present. In doing so, we illustrate the similarity between the modes of governance used in the Semester and the Governance Regulation. 


\subsection{The European Semester: overview}

The European Semester is the EU's six-month fiscal planning process, synchronising the surveillance, reporting and enforcement elements of both the Stability and Growth Pact (SGP) - which sets targets for national debt and deficits - and the Europe 2020 Strategy - which promotes jobs and growth in the Union. It responds to perceived weaknesses in the Economic and Monetary Union and the SGP by establishing an ongoing process of surveillance of national budgets. National governments report on progress towards priorities adopted at EU level, including via the Europe 2020 Strategy, and the European Commission monitors performance against a set of agreed indicators. Where a country is found lacking, its government must explain its decisions, take remedial action and, if still considered to pose a threat to EU-wide economic stability, face sanctions.

The cycle starts with the Annual Growth Survey (AGS), in which the Commission assesses priorities for the EU as a whole. National governments communicate their plans in response to this, and the EU makes recommendations to each member state. Though formally non-binding, these Country-Specific Recommendations (CSRs) can trigger coercive responses for those countries subject to the Excessive Deficit Procedure or the Macroeconomic Imbalance Procedure. In each of these instances, sanctions are decided by reverse-qualified majority voting, meaning that they are imposed automatically save for a blocking vote by a qualified majority. As such, whilst it draws heavily on the instruments and processes of the OMC, what distinguishes the Semester is the potential for its 'soft' recommendations to become 'hard' requirements where member states fail to abide by the rules (Bauer \& Becker, 2014).

The Semester was not designed as a tool of health governance but, since health makes up a significant proportion of expenditure in all member states, health systems became a target of efforts to induce fiscal sustainability. Health at the EU level has historically been governed by policy frameworks and competences outside of health, such as the internal market (Greer, 
2014), but the Semester constitutes a marked change in two ways. Firstly, it extends EU action into the realm of healthcare financing and organisation - arguably the most sensitive area of national health policy. Secondly, it does so using a combination of soft and hard instruments, making member states' discretion to ignore recommendations dependent upon their fiscal situation (Stamati \& Baeten, 2015; interview 19). Few of these instruments are new to health - not least of all because most are duplicated from the healthcare OMC - but the extent to which they are binding, their linkage with other policies and the scale of the policy surveillance which accompanies them is novel, as explored below.

\subsection{The Governance Regulation: overview}

Energy and climate objectives were included in early cycles of the Semester and low-key dialogue between member states and the Commission, within the Semester's framework, was taking place. However, Commission officials report that climate and energy policy remained at the periphery in a process driven by the response to the economic crisis and the perceived need to reinforce macroeconomic coordination; energy did not feature prominently in the CSRs (interviews 2, 4). Despite this limited influence of the Semester, the Council of the EU requested that when a dedicated framework for the governance of the Energy Union was to be created, it be modelled on the Semester (interviews 1, 2,3).

The Energy Union, which includes the Clean Energy Package for 2030, constitutes a shift in energy governance. Unlike the 2020 framework - the so-called Climate and Energy Package adopted in 2009 - the Clean Energy Package no longer includes nationally binding targets, except for climate change. To ensure monitoring of progress and compliance, the Package includes an innovative piece of legislation, the Governance Regulation. This stipulates that member states set their own objectives and pathways towards meeting EU targets through

National Energy and Climate Plans (NECPs). The overarching purpose of the Governance 
Regulation is different from the crisis-driven Semester; it seeks to set a positive, proactive agenda for shaping further integration. Yet it contains many elements similar to the Semester - for instance, the Commission's national recommendations - and provisions have been made for complementarity between the two governance architectures (interview 4).

Addressing our first research question we examine the specific instruments, processes and actors that the Semester and the Governance Regulation involve. We show that the primary components of the experimentalist 'cycle' can be identified in both the Semester and the Governance Regulation, but that harder elements, not foreseen by the Experimentalist Governance framework, are also present.

\subsection{Framework goals}

Within the Semester, framework goals are set by the AGS. There were originally three overarching priorities for the EU: 'rigorous fiscal consolidation, 'labour market reforms' and 'growth-enhancing measures' (European Commission, 2010). For health, the goals in the AGS have varied in their specificity, with early Surveys calling for broad reforms to promote 'costeffectiveness and sustainability' (European Commission, 2011, p. 5) and later iterations providing more detailed encouragement to 'provide quality health care through efficient structures, including eHealth' (European Commission, 2014, p. 13), for instance. The CSRs embody the agreed routes by which member states will pursue the goals, in light of their particular national contexts, and thus serve as metrics by which progress can be measured. For example, CSRs might advise member states to 'implement... administrative reform with a view to better cost-effectiveness of...healthcare services' (Council of the EU, 2016, p. 82).

Whilst the Semester implements the hard targets of the SGP - which limit government deficits to $3 \%$ of GDP and debts to $60 \%$ of GDP, and are sanctionable save for a blocking vote in the Council - it does not set its own hard framework goals. The exception here is the Excessive 
Deficit Procedure (EDP) and the Macroeconomic Imbalance Procedure, in which member states that have deviated from the SGP ceilings are issued with recommendations drawn from the CSRs, and face sanctions if they do not comply. In one instance, this has presented a remarkable situation for health policy. Whilst under the EDP, France had a CSR urging it to fundamentally restructure its health workforce policy by abolishing its long-standing annual limit on the recruitment of medical students (European Council, 2015). France exited the EDP relatively quickly, and thus escaped having to comply with the requirement, but the case illustrated the potential for unprecedented EU influence over a national health system, borne from the hardening of a framework goal (Greer \& Jarman, 2018).

In energy, the framework goals of the Energy Union are defined at the central level, in a more precise fashion than in health. These include the 2030 targets for GHG emission reductions ($40 \%)$, renewable energy supply (32\%) and energy efficiency (32.5\%) as well as other headline objectives such as transnational interconnections for electricity (15\%). These goals were enshrined in legislation as part of the 2018 'Clean Energy Package'. However, they are not all of the same legal nature. While the emission reduction objective is binding at both EU and national levels, and directly enforceable, the renewable energy target is binding at the EU level only and energy efficiency targets are non-binding at both levels. ${ }^{\text {ii }}$ Associated legislation, such as the revised Renewable Energy Directive, define precisely how to measure progress and what counts towards achieving the targets.

In terms of framework goals, we therefore observe contradictory dynamics across the two sectors. In health, a shift towards HSG has come primarily via specificity. The health-related framework goals set in the AGS have become more precise, limiting the flexibility available to governments and challenging their ability to claim compliance with vaguely-worded recommendations (Baeten \& Vanhercke, 2017). As noted in energy, the Clean Energy Package 
for 2040 no longer includes nationally binding renewable energy targets as was the case in the 2020 energy and climate framework, with them binding only at EU level. The dynamic here is thus one of partial softening of framework goals.

\subsection{Lower level unit responsibility and reporting}

The lower-level units responsible for achieving the framework goals are, across both the Semester and the Governance Regulation, the member states. In the Semester, governments are required to submit Stability or Convergence Programmes, which serve as public reporting on adjustment towards the SGP rules, National Reform Programmes (NRPs), detailing progress towards the goals of Europe 2020 and, for euro area states, Draft Budgetary Programmes, through which the EU exercises ex ante control over fiscal policies. In addition to being formal requirements of the Semester process, these reporting mechanisms serve as platforms for member states to justify their actions. In the NRPs, for instance, governments have to specify precisely which policies they will introduce to boost jobs and growth, and correct imbalances (Eurofound, 2018). For example, Belgium's 2014 NRP details the specific assessment instrument introduced to assess patients and various other policies which will contribute to achieving the CSR on increasing the cost-effectiveness of long-term care (Belgian government, 2014, pp.8-9). Moreover, the NRPs are themselves based on Commission guidance issued in the Broad Economic Policy Guidelines and inform the drafting of the CSRs (Eurofound, 2018), reinforcing the cycle of policy influence and hardening these soft reporting mechanisms.

Similar reporting structures are seen within the Governance Regulation, building on preexisting requirements fragmented across different pieces of legislation. For instance, the 2009 Renewable Energy Directive included a process of regular reporting of progress towards achieving EU and national 2020 targets (Howes, 2010). The 2012 Energy Efficiency Directive included a similar mechanism (EP and the Council, 2012). The Governance Regulation reinforces reporting requirements through their harmonisation into a single framework for all 
Energy Union objectives - 'to streamline and bring together separate planning and reporting strands' (European Parliament and Council, 2018a, p. 8).

The Governance Regulation also introduces a novel 'pledge and review' process. This is partially modelled on the Semester but also, and perhaps more importantly, on the 2015 Paris [Climate] Agreement, which is decentralised and non-binding at the national level (Oberthür, 2019). Member states must submit integrated 10-year NECPs to the Commission, representing their contribution towards meeting EU framework goals. Although the Commission is mainly tasked with monitoring and compliance, the drafts include information defined in broad terms in the Governance Regulation and further specified through templates set up by the Commission and a continuous informal dialogue. ${ }^{\text {iii }}$ The Commission also takes stock of national pledges and identifies any ambition - and later implementation - gaps. The Commission evaluates NECPs and can issue recommendations to member states, although these are non-binding, since a large number of member states were adamant about retaining their ability to define their own national trajectories and instruments (interviews 3, 6, 8, 13).

\subsection{Periodic revision}

The framework goals, metrics and processes of the Semester have changed considerably since it was launched in 2010. Through this revision, a process of 'socialisation' is well-recorded in the literature (Zeitlin \& Vanhercke, 2018) and traces the increasing emphasis on social objectives, the expansion of social policy monitoring and surveillance, and the growing role of social policy actors (European Commission, 2018b). For instance, in health, the framework goals have broadened from cost-containment to universal access to healthcare (as featured in the latest AGS) and the metrics and indicators used to monitor progress have expanded to include data on unmet medical need and out-of-pocket payment for health services (interview $18)$. 
The Governance Regulation also provides for periodic revision. The Commission will issue an annual State of the Energy Union report that tracks progress towards EU objectives. By 2023, the Commission will review progress towards achieving the 2030 goals and its commitments as part of the Paris agreement, 'including provision for a review and potential increase in the Union-level target' (EP and the Council, 2018a, p. 5). This upwards revision clause would be triggered, for example, if the EU suffers from an ambition or implementation gap related to the 2030 targets. The changes to targets between 2014 and 2018 - where the target for renewable energy was upgraded from $27 \%$ to $32 \%$, and for energy efficiency from $27 \%$ to $32.5 \%-$ demonstrates the potential for upwards revision.

\section{The harder-edge of Experimentalist Governance}

The Semester and Governance Regulation are comprised of a similar set of soft, experimental instruments and mechanisms; however, we find a number of additional HSG elements are also present.

\subsection{Penalty defaults \& the shadow of hierarchy}

Both the Semester and the Governance Regulation exhibit harder features in the form of 'penalty defaults', perhaps even more centrally than the Experimentalist Governance framework would suggest. In health, Greer and Vanhercke identify clearly the default penalty which encouraged health actors to engage in the OMC on health: 'the penalty for lack of action is progressive submission to internal market law as extended in an unpredictable, case-by-case manner' (2010, p. 222). This example closely reflects the kind of penalty envisaged by Zeitlin (2008) - who points to the unpredictability of the EU competition law regime as a particularly strong source of penalty defaults - but is less relevant in the case of the Semester, where the EU has little competence to govern the areas of health targeted. Instead, the penalty here is that actors with less knowledge of (and potentially regard for) health, led by the Commission's 
Economic and Financial Affairs directorate, will be responsible for drafting recommendations which impact upon health (Stamati \& Baeten, 2015, p. 189; interview 20). Health ministers were initially induced to engage by the realisation that, if they did not, their counterparts in treasury and finance ministries would continue to make policy which affected health without due concern (interviews 15, 16; Fierlbeck, 2014, p. 93). They were struck by the reality that 'even if they are not at the [Semester] table, they will remain on the menu' (interview 17).

The Governance Regulation also rests on a hard edge. First, some energy objectives are binding and enshrined in legislation, which makes them, to an extent, directly enforceable by the Court (e.g. Greenhouse gas emission reduction targets in non-ETS sector, eco-design provisions). Second, although the renewable energy target is only binding at the EU level, included in the Annex is an indicative formula for the calculation of national objectives to achieve the EU goal (EP and the Council, 2018b: Annex II). These come close to national targets and provide a clear benchmark to assess individual national failures and 'laggards' (interviews 5, 9). Indeed, in its recommendations of June 2019 on the very first NECPs, the Commission has not shied from using the formula to recommend more ambition on renewable energy from 12 states (Euractiv, 2019). Third, the Commission is empowered to adopt delegated acts to bring the Governance Regulation in line with the evolution of the EU's long term energy and climate strategy as part of the Paris agreement (Article 43). Fourth, if there is an ambition or implementation gap, the Commission 'shall propose measures and exercise its powers at Union level in order to ensure the collective achievement of...objectives and targets' (Article 31). These mechanisms serve as clear penalty defaults to encourage cooperation within the Governance Regulation framework. Given the existence of substantive EU competences on climate and energy, and the fact that the Governance Regulation is supported by associated legislation, it can be argued that it relies to a greater extent on the 'shadow of hierarchy' than health. 


\subsection{Hardening soft governance}

Three other elements of HSG, not directly included within the Experimentalist Governance framework, are the creation of a high threshold for change, the involvement of and institutionalisation of additional actors, and policy coupling.

High thresholds for change have been installed at two key points of the Semester. Firstly, overturning of fines for non-compliance with the deficit procedure requires a reverse qualified majority - i.e. a qualified majority of states to challenge, rather than to approve - making sanctions 'automatic' by default. Secondly, amendment of the CSRs proposed by the Commission requires a 'reinforced' qualified majority in the Council. ${ }^{\text {iv }}$ This is combined with a 'comply or explain' rule compelling the Council to publicly justify the change sought (Zeitlin \& Vanhercke, 2018, p. 161), a requirement that amendments may not 'reduce a member state's effort', and a short timeframe for their agreement; 'as a result, no substantial amendments to health CSRs have yet been approved by the Council' (Baeten \& Vanhercke, 2017, pp. 489-90).

In the Governance Regulation the high threshold for change is of a different nature. The recommendations of the Commission are non-binding - member states only have to take 'due account' and respond. However, several targets and obligations are binding as they are enshrined in associated legislation. Change would require the Commission to issue new legislative proposal(s) to be adopted by the legislature.

A second element of HSG is the institutionalisation of political entrepreneurs - namely, civil society actors. A full exposition of the dynamics which have unfolded in the Semester is beyond the scope of this article (on its 'socialisation' see Zeitlin \& Vanhercke, 2018), but as the role of civil society has increased over successive cycles, so the specificity of relevant recommendations and public accountability of the process has increased. For instance, the Semester process has evolved to provide for greater involvement of health ministries, civil 
society actors and the Commission's health directorate, whilst the latter has significantly increased its expertise in health system performance assessment and aggregation of countryspecific health information to ensure its involvement (Brooks, 2015; interviews 14, 18, 19).

In energy, the involvement of civil society is expected to be a key part of the process. The plans and recommendations have been made public, and it is hoped that this increased transparency will facilitate peer pressure from other governments at the EU level, and public criticism at the national level from stakeholders and civil society actors (e.g. environmental NGOs), forcing them to justify themselves to one another, the EU institutions and the public, and to change course if needed (interviews 3, 4, 5, 8, 9, 11). The publication of the Commission's first summary of Recommendations in June 2019 (Commission, 2019) was followed by extensive media coverage and criticism from NGOs (The Guardian, 2019).

Finally, instances of policy coupling can be seen in both governance architectures. In the Semester, the rules of the 2014-2020 European Structural and Investment Funds (ESIF) enable the Commission to request a government to direct part of any funding that it receives in pursuit of its CSRs, making the ESIF a 'potential lever for implementation of the CSRs' (Baeten \& Vanhercke, 2017, p. 491). The Governance Regulation, meanwhile, connects in novel and formal ways processes of reporting and progress monitoring for energy and climate through the integrated NECPs. Interviewees referred to a Governance Regulation objective of developing the coherence and coordination between climate and energy policy; 'breaking the silos' (interviews 7, 8). Arguably, coupling energy to climate policy, a more established policy area which benefits from strong support and momentum, can be interpreted as a way to consolidate EU energy policy. 
Table 1: Harder elements in the governance of health and energy

\begin{tabular}{|c|c|c|c|}
\hline Mechanism & Description & Health - Semester & Energy - The Governance Regulation \\
\hline $\begin{array}{l}\text { 'Hard' } \\
\text { targets/implementation }\end{array}$ & $\begin{array}{l}\text { Reshaping voluntarism by } \\
\text { introducing 'hard' } \\
\text { targets/obligations or } \\
\text { implementation. }\end{array}$ & $\begin{array}{l}\text { The Semester implements the binding SGP } \\
\text { debt and deficit targets. }\end{array}$ & $\begin{array}{l}\text { GHG (EU \& national) and renewable (EU only) targets } \\
\text { binding. Energy efficiency headline target non-binding; } \\
\text { specific targets binding. }\end{array}$ \\
\hline $\begin{array}{l}\text { Naming, blaming and } \\
\text { shaming }\end{array}$ & $\begin{array}{l}\text { Through increased publicity; public } \\
\text { information; country rankings, } \\
\text { public databases. }\end{array}$ & $\begin{array}{l}\text { Country-specific analysis in the Country } \\
\text { Reports; 'Social scoreboard'. }\end{array}$ & $\begin{array}{l}\text { NECP plans made public to increase transparency and peer } \\
\text { pressure on laggards. }\end{array}$ \\
\hline $\begin{array}{l}\text { Institutionalising } \\
\text { political entrepreneurs }\end{array}$ & $\begin{array}{l}\text { Strengthening the role of potential } \\
\text { political entrepreneurs by giving } \\
\text { them political role. }\end{array}$ & $\begin{array}{l}\text { The institutionalised role of social actors } \\
\text { and civil society. }\end{array}$ & $\begin{array}{l}\text { Publicising drafts, plans and gaps to foster civil society } \\
\text { participation in/and accountability. }\end{array}$ \\
\hline Justification & $\begin{array}{l}\text { Ensure States justify (non)reaction } \\
\text { towards policy recommendation of } \\
\text { higher/European level. }\end{array}$ & $\begin{array}{l}\text { Amendments to CSRs require public } \\
\text { justification; National Reforms } \\
\text { Programmes serve as justification on } \\
\text { progress. }\end{array}$ & $\begin{array}{l}\text { Governments must publicly respond to Commission } \\
\text { recommendations re ambition gap(s). }\end{array}$ \\
\hline Policy field coupling & $\begin{array}{l}\text { Linking soft governance policy } \\
\text { fields to provide financial } \\
\text { incentives / sanctions. }\end{array}$ & $\begin{array}{l}\text { Linked with European Structural and } \\
\text { Investment Funds. }\end{array}$ & $\begin{array}{l}\text { Harnesses energy objectives to climate governance (e.g. } \\
\text { emissions reporting). }\end{array}$ \\
\hline Sanctions & $\begin{array}{l}\text { Introduction of sanctions or } \\
\text { financial penalties in case of non- } \\
\text { compliance etc. }\end{array}$ & $\begin{array}{l}\text { Excessive Deficit Procedure and } \\
\text { Macroeconomic Imbalance Procedure both } \\
\text { entail sanctions. }\end{array}$ & $\begin{array}{l}\text { Only climate targets enforced by Court. States required to } \\
\text { follow the process (timely submission of plans, complete } \\
\text { submission). }\end{array}$ \\
\hline Tertiary legislation & $\begin{array}{l}\text { The Commission can issue } \\
\text { implementing/ delegated acts to } \\
\text { exert pressure. }\end{array}$ & N/A. & $\begin{array}{l}\text { Commission can issue delegated acts to bring EU } \\
\text { framework in line with the Paris Agreement, and propose } \\
\text { secondary legislation if ambition/implementation gap. }\end{array}$ \\
\hline $\begin{array}{l}\text { Specificity / tangibility } \\
\text { of recommendations }\end{array}$ & $\begin{array}{l}\text { Rather than vague objectives, } \\
\text { specific targets and timelines. }\end{array}$ & $\begin{array}{l}\text { CSRs and Country Reports identify } \\
\text { tangible policy targets. }\end{array}$ & $\begin{array}{l}\text { Commission templates for NCEPs. Renewables formula to } \\
\text { provide guidance on objectives and benchmarks. }\end{array}$ \\
\hline $\begin{array}{l}\text { High threshold for } \\
\text { amendment / change / } \\
\text { input }\end{array}$ & $\begin{array}{l}\text { Changing instrument or } \\
\text { recommendation requires consensus } \\
\text { or is difficult to achieve. }\end{array}$ & $\begin{array}{l}\text { Amendment to CSRs and opposition to } \\
\text { sanctions requires reinforced and reversed } \\
\text { qualified majority respectively. }\end{array}$ & $\begin{array}{l}\text { Change to EU/national objectives requires legislative } \\
\text { change under the Ordinary Legislative Procedure, using } \\
\text { Qualified Majority Voting (Commission proposal, } \\
\text { agreement of the Council and the European Parliament). }\end{array}$ \\
\hline $\begin{array}{l}\text { Enhanced (or variable } \\
\text { degrees of) } \\
\text { surveillance }\end{array}$ & $\begin{array}{l}\text { Where certain conditions are met, } \\
\text { more intensive policy surveillance } \\
\text { initiated. }\end{array}$ & $\begin{array}{l}\text { Member states subject to EDP are subject } \\
\text { to enhanced monitoring. }\end{array}$ & $\begin{array}{l}\text { Standardised, comprehensive process of reporting. } \\
\text { Publication of detailed national plans, based on templates, } \\
\text { enable the Commission to track progress. }\end{array}$ \\
\hline
\end{tabular}

Source: Adapted by authors from Knodt \& Schoenefeld (forthcoming). 


\section{Exploring drivers of the shift in governance}

Addressing our second research question, we explore the drivers of the change in governance of health and energy policies, and consider the possible lessons learned from the European Semester for the Governance Regulation.

The need to circumvent a lack of formal competences and/or sovereignty concerns in sensitive areas has been a key driver of the shift in governance. Both health and energy might be considered core state powers - i.e. essential aspect of its raison d'être and legitimacy. It might then be expected that member states would fight further EU encroachment fiercely. For health in the Semester, the recourse to hard law - or laying the groundwork for future legislation - is not a potential source of pressure, since health system organisation and financing are outside of the EU's competence. Moreover, health actors and the Commission more broadly did not create the Semester with the intention of encroaching this competence - whilst they are now seeking to utilise it in pursuit of health objectives, this a reactive strategy.

As such, whilst the hardening of fiscal sustainability rules within the Semester as a whole might be driven by a need to circumvent non-compliance with the SGP, utilisation of a HSG framework in health is a result of creative opportunism on the part of health actors and, in particular, the Commission's health directorate. Officials view the Semester as an opportunity to consolidate and extend the EU's health system agenda (interviews 24, 25; Baeten \& Thomson, 2012: 10; Brooks, 2015) and states now receive CSRs on areas core to health system organisation, indicating extended European integration (Azzopardi-Muscat et al., 2015, p. 380; Greer, 2014). Civil society actors have been key to this pro-active strategy, contesting the ownership of finance actors over the process (Sabato et al., 2017, p. 18; Stamati \& Baeten, 2015, p. 189). 
In energy, concerns about security and sovereignty have long limited national governments' willingness to delegate further power to the EU level in energy policy (Padgett, 1992), and the exploitation of national energy resources, the determination of the energy mix and taxation remained firmly national prerogatives. It is largely on sovereignty grounds that the European Council did not endorse binding national renewable energy targets in 2014 (The Guardian, 2014).

Supranational activism is less clear cut, as the Governance Regulation mainly builds on already existing EU competences and Commission's prerogatives. Where powers for the Commission can be argued to have been enhanced, including the surveillance and publicity of member state plans, this is linked to, and compensation for, member states guarding their sovereignty by insisting on the removal of national targets for renewables (interviews 8,10 ); this compensation was also strongly driven by member states such as Germany and France (interviews 7, 10) so is less clearly a result of the Commission seeking to extend its authority but rather to safeguard it (interview 15). In the absence of hard national targets enforceable by the Court, the Commission, European Parliament and some member states were concerned about the ability of the EU to reach its collective target and about the risk of free-riding by less ambitious countries (interviews 10,13). The Governance Regulation was therefore partially designed as a second-best solution to accommodate national sovereignty concerns. It provides flexibility while inserting national plans into a collective monitoring process under the Commission's leadership to facilitate convergence towards common objectives. The Governance Regulation can be regarded as a partial softening of an already existing legal framework - for renewable energy - although not in an unambiguous way, given that the monitoring role of the Commission has been significantly strengthened (Oberthür, 2019).

\section{Conclusion}


The Semester and the Governance Regulation exhibit many features of Experimentalist Governance, structured primarily around a cycle of target setting, reporting, surveillance and coordination. However, where they diverge from the Experimentalist Governance model is in their inclusion of elements of HSG. In both cases, simple soft instruments, such as reporting, are hardened by mechanisms of publication, public justification and specificity. The Semester is '...arguably, the "hardest" form of soft law' (Garben, 2018, p. 222), combining instruments well-known from the OMC with 'hard edges' like the deficit and imbalance procedures (Dawson, 2018, p. 199). The Governance Regulation is in part built on hard legislation climate legislation, renewable energy directive and efficiency legislation - or in the shadow of new legislation, in case framework goals are not met.

In both cases, we find that the shift towards HSG is driven by a common dynamic; the need to alleviate member states' sovereignty concerns and weak or incomplete competences. Where heath and energy differ is in the nature of the countervailing dynamic. In health, HSG has emerged from the creative entrepreneurship of health actors. In energy, HSG results more from the need to ensure compliance in the absence of hard national targets - for renewable energy and energy efficiency at least - while respecting sovereignty concerns.

From our review of the experience of health within the Semester and similarities with the Governance Regulation, we draw particular attention to three implications for energy policy. First, policy coupling is an important and influential hardening mechanism. Though not unprecedented, the Semester has raised the profile of linkages between EU funds and broader policy objectives. Particularly where horizontal issues such as climate change are concerned in which EU competences and legitimacy are more firmly established - this presents a potential future avenue for further hardening of the Governance Regulation. It is not unforeseeable that the climate emergency and pressure arising from international climate negotiations may lead to an expansion of the reach of the Governance regulation. Second, the operation and evolution 
of the Governance Regulation will depend in large part upon the engagement and approach of relevant actors. The Governance Regulation provides an avenue for creative opportunism and the health, and broader social, policy experience through the European Semester illustrates the impact that this can have upon the direction and operation of the governance architecture, by altering objectives and accountability. Finally, situations of crisis have the potential to expand the reach of soft governance frameworks, introduce elements of HSG into them and institutionalise new fields of EU influence. Following the creation of a new 'EU health systems agenda', it is not difficult to imagine a scenario in which concerns about security - traditional and/or environmental - might see a similar extension of EU involvement in areas of energy policy currently governed by soft law alone. 


\section{References}

Abbott, K., \& Snidal, D. (2000). Hard and soft law in international governance. International Organization, 54(3), 421-456.

Azzopardi-Muscat, N., Clemens, T., Stoner, D., \& Brand, H. (2015). EU Country Specific Recommendations for health systems in the European Semester process: Trends, discourse and predictors. Health policy, 119(3), 375-383.

Baeten, R., \& Thomson, S. (2012). Health care policies: European debate and national reforms. In D. Natali \& B. Vanhercke (Eds.), Social developments in the European Union 2011 (pp. 187-211). Brussels: ETUI.

Baeten, R., \& Vanhercke, B. (2017). Inside the black box: The EU's economic surveillance of national healthcare systems. Comparative European Politics, 15(3), 478-497.

Bauer, M. \& Becker, S. (2014). The Unexpected Winner of the Crisis: The European Commission's Strengthened Role in Economic Governance. Journal of European Integration, 36:3, 213-229.

Borras, S., \& Radaelli, C. (2011). The politics of governance architectures: creation, change and effects of the EU Lisbon Strategy. Journal of European Public Policy, 18(4), 463484.

Brooks, E. (2015). Health ownership of health policy? Challenges and concerns in the new era of EU health policy. Eurohealth, 21(4). Retrieved from http://www.lse.ac.uk/LSEHealthAndSocialCare/pdf/eurohealth/EuroHealth-v21n4LAYOUT-14Dec15-webFinal.pdf.

Caporaso, J. and Wittenbrinck, J. (2006). The new modes of governance and political authority in Europe, Journal of European Public Policy, 13(4): 471-480.

Council of the EU. (2016). Council Recommendation on the 2016 National Reform Programme of Finland and delivering a Council opinion on the 2016 Stability Programme of Finland. (2016/C 299/19). Retrieved from https://eur-lex.europa.eu/legalcontent/EN/TXT/?uri=uriserv\%3AOJ.C_.2016.299.01.0079.01.ENG\&toc=OJ\%3AC \%3A2016\%3A299\%3ATOC.

Dawson, M. (2018). New governance and the displacement of Social Europe: the case of the European Semester. European Constitutional Law Review, 14, 191-209.

Dehousse, R. (2016). Has the European Union moved towards soft governance? Comparative European Politics, 14(1): 20-35.

De la Porte, C., \& Heins, E. (2016). A new era of European integration? Governance of labour market and social policy since the sovereign debt crisis. Comparative European Politics, 13(1), 8-28.

Eberlein, B., \& Kerwer, D. (2004). New Governance in the European Union: A Theoretical Perspective. Journal of Common Market Studies, 42(1), 121-142.

Euractiv (2019) NECP recommendations, 14 June 2019. https://www.euractiv.com/wpcontent/uploads/sites/2/2019/06/NECP-recommendations.pdf

Eurofound. (2018). National Reform Programmes. Retrieved from https://www.eurofound.europa.eu/observatories/eurwork/industrial-relationsdictionary/national-reform-programmes. 
European Commission. (2010). Annual Growth Survey 2011. COM(2011) 11 final.

Retrieved from

http://ec.europa.eu/economy_finance/articles/eu_economic_situation/pdf/2011/com20

11_11_en.pdf

European Commission. (2011). Annual Growth Survey 2012. COM(2011) 815 final.

Retrieved from https://eur-lex.europa.eu/legal-

content/EN/TXT/?uri=CELEX\%3A52011DC0815.

European Commission. (2014). Annual Growth Survey 2015. COM(2014) 902 final.

Retrieved from https://ec.europa.eu/info/system/files/2015-european-semester-annual-

growth-survey-en.pdf.

European Commission. (2018b). Press Release accompanying the publication of the

European Semester Winter Package. (IP/18/1341). Retrieved from

http://europa.eu/rapid/press-release_IP-18-1341_en.htm.

European Commission. (2019) 'Setting the foundations for a successful clean energy transition', Brussels, 18th June,

https://ec.europa.eu/energy/sites/ener/files/documents/recommondation_en.pdf

European Council. (2000). Presidency Conclusions from the Lisbon European Council, 23-24

March 2000. Retrieved from http://www.europarl.europa.eu/summits/lis1_en.htm.

European Council. (2015). Council recommendation delivering an opinion on the SCP of France. 2015/C 272/14, 18.8.2015.

European Parliament and Council (2012) 'Directive 2012/27/EU of The European

Parliament and of The Council Of 25 October 2012 on energy efficiency', 14

November.

European Parliament and Council (2018a) 'on the Governance of the Energy Union and Climate Action'. Retrieved from https://data.consilium.europa.eu/doc/document/PE55-2018-INIT/en/pdf.

European Parliament and Council (2018b) 'on the promotion of the use of energy from renewable sources (recast)'. Retrieved from https://eur-lex.europa.eu/legalcontent/EN/TXT/PDF/?uri=CELEX:32018L2001\&from=EN.

Fierlbeck, K. (2014). The changing contours of experimental governance in European health care. Social Science and Medicine, 108, 89-96.

Garben, S. (2018). 'The European Pillar of Social Rights: Effectively addressing displacement?' European Constitutional Law Review, 14, 210-30.

Graziano, P. R., \& Halpern, C. (2016) 'EU governance in times of crisis: Inclusiveness and effectiveness beyond the 'hard'and 'soft'law divide'. Comparative European Politics, 14(1), 1-19.

Greer, S. (2014). The three faces of European Union health policy: Policy, markets, and austerity. Policy and Society, 33(1), 13-24.

Greer, S. and Jarman, H. (2018). European citizenship rights and European fiscal politics after the crisis. Government and Opposition, 53(1), 76-103.

Greer, S., \& Vanhercke, B. (2010). The hard politics of soft law: the case of health. In E. Mossialos, G., Permanand, R., Baeten \& T. Hervey (Eds.), Health systems governance in Europe: the role of European Union law and policy (pp. 186-230). Cambridge: Cambridge University Press. 
The Guardian. (2014). EU leaders agree to cut greenhouse gas emissions by $40 \%$ by 2030.24 October, https://www.theguardian.com/world/2014/oct/24/eu-leaders-agree-to-cutgreenhouse-gas-emissions-by-40-by-2030

The Guardian. (2019). EU climate goals 'just a collection of buzzwords', say critics. 10 June, https://www.theguardian.com/world/2019/jun/10/eu-priorities-climate-buzzwordscritics

Héritier, A., \& Lehmkuhl, D. (2008) 'The shadow of hierarchy and new modes of governance'. Journal of public policy, 28(1), 1-17.

Howes, T. (2010). The EU's new renewable energy Directive (2009/28/EC). In S. Oberthür \& M. Pallemaerts (Eds.), The New Climate Policies of the European Union (pp. 117-150). Brussels: VUB Press.

Keohane, R. \& Victor, D. (2015). After the failure of topdown mandates: The role of experimental governance in climate change policy. In S. Barrett, C. Carraro and J. De Melo (Eds), Towards a workable and effective climate regime (pp. 201-212) London: Centre for Economic Policy Research.

Knodt, M. and Schoenefeld, J. (forthcoming). Introduction: "Harder Soft-Governance" in European Climate and Energy Policy: Following a New Trend?'.

Maher, I. (2004). Law and the Open Method of Coordination: Towards a new flexibility in European policy-making? Journal for Comparative Government and European Policy, 2(2), 248-262.

Müller, F., Knodt, M. and Piefer, N. (2015). Conceptualizing emerging powers and EU energy governance: Towards a research agenda. In N. Piefer \& F. Müller (Eds) Challenges of EU external energy governance towards emerging powers (pp. 17-27) Ashgate: Routledge.

Oberthür, S. (2019). Hard or soft governance? The EU's Climate and Energy Policy Framework for 2030. Politics and Governance, 7(1), 17-27.

Padgett, S. (1992). The single European energy market: The politics of realization. Journal of Common Market Studies, 30(1), 53-76.

Radaelli, C. (2008). Europeanization, policy learning, and new modes of governance. Journal of Comparative Policy Analysis, 10(3): 239-254.

Ringel, M., \& Knodt, M. (2018). The governance of the European Energy Union: Efficiency, effectiveness and acceptance of the Winter Package 2016. Energy Policy, 112, 209220.

Sabato, S., Vanhercke, B. and Spasova, S. (2017). Listened to, but not heard? Social partners' multilevel involvement in the European Semester. Brussels: European Social Observatory.

Sabel, C. and Zeitlin, J. (2008). Learning from Difference: The New Architecture of Experimentalist Governance in the EU. European Law Journal, 14(3), 271-327.

Sabel, C. \& Zeitlin, J. (2010a). Learning from difference: The new architecture of Experimentalist Governance in the EU. In C. Sabel \& J. Zeitlin (Eds.), Experimentalist Governance in the European Union: Towards a new architecture (pp. 1-28). Oxford: Oxford University Press.

Sabel, C. \& Zeitlin, J. (Eds) (2010b). Experimentalist Governance in the European Union: Towards a new architecture. Oxford: Oxford University Press. 
Saurugger, S., \& Terpan, F. (2016). Resisting 'new modes of governance': An agency-centred approach. Comparative European Politics, 14(1), 53-70.

Stamati, F. \& Baeten, R. (2015). Varieties of healthcare reform: understanding EU leverage. In D. Natali \& B. Vanhercke (Eds.), Social Policy in the European Union: State of play 2015 (pp. 183-214). Brussels: European Trade Union Institute ETUI.

Trubek, D. \& Trubek, L. (2005). Hard and soft law in the construction of Social Europe: the role of the Open Method of Coordination. European Law Journal, 11(3), 343-364.

Verdun, A. \& Zeitlin, J. (2017). Introduction: the European Semester as a new architecture of EU socioeconomic governance in theory and practice. Journal of European Public Policy, 25(2), 137-148.

Zeitlin, J. (2005). Conclusion: The open method of co-ordination in action: theoretical promise, empirical realities, reform strategy. In: J. Zeitlin, P. Pochet \& L. Magnusson (eds.) The Open Method of Co-Ordination in Action: The European Employment and Social Inclusion Strategies. (pp.447-503). Brussels: Peter Lang.

Zeitlin, J. (2008). The Open Method of Co-ordination and the governance of the Lisbon Strategy. Journal of Common Market Studies, 46(2), 436-450.

Zeitlin, J. \& Vanhercke, B. (2018). Socializing the European Semester: EU social and economic policy co-ordination in crisis and beyond. Journal of European Public Policy, 25(2), 149-174. 


\section{Appendix 1: List of interviewees}

1. Think tank representative, 13.04.18

2. DG Energy, 02.07.18

3. European Parliament, 05.07.18

4. European Commission, 02.07.18

5. Senior EU official, 10.04.18

6. Polish official, 09.04.18

7. DG Energy, 13.04.18

8. Swedish official, 29.06.18

9. Member state official, 02.07.18

10. Journalist, 04.07.18

11. Member state official, 04.07.18

12. Member state official, 05.07.18

13. Journalist, 06.07.18

14. Council Official, 22.06.17

15. Member state official, 22.06.17

16. Member state official, 23.06.17

17. Health NGO, 23.06.17

18. Social Protection Committee, 06.07.17

19. DG ECFIN, 07.07.17

20. European Parliament official, 07.07.17

21. DG Sante, 08.07.15

\section{Endnotes}

\footnotetext{
i The dominant model of governance since the inception of the Communities in 1957 (Eberlein \& Kerwer, 2004). The Community Method empowers the European Commission as the sole legislative initiator, the Council of the EU (and then the European Parliament) as decision-maker(s), and the Court of Justice for adjudication and enforcement.

ii Although some sub-targets included in the Energy Efficiency Directive and Ecodesign legislation are harder.

iii 'A structured, transparent, iterative process between the Commission and Member States' (Article 1).

iv $72 \%$ of member states, accounting for $65 \%$ of the EU population.
} 